\title{
The ITALIAN CHURCH IN THE YEAR OF THE PAPAL SUCCESSION
}

\author{
Alberto Melloni
}

Arturo Carlo Jemolo wrote Church and State during the Last Hundred Years in 1948. Jemolo, an insightful scholar of a relationship that has been scrutinized from all angles, continually updated his "long-seller," publishing fresh editions at various points. It was even reprinted after his death. By this time, historiographical knowledge of the single segments of that experience had increased in significant ways. Yet there is one reason in particular that explains this book's resistance to both the progress of time and advances in research and illustrates why it still deserves our attention today. Jemolo had intuited the broad chronological dimension that was and still remains indispensable in order to understand the relationship between church and state in Italy. If we did not precisely place the phenomena on a wide parabola, we would, in fact, risk confusing episodes with tendencies, outcomes with processes-and, in the end, become prisoners (if I may pun on the subtitle of the newspaper Osservatore Romano) of a "political and religious daily" life in which the ephemeral becomes memorable, and vice versa.

Ever more so today, we need to proceed with caution in evaluating the aspects of the life of the Catholic Church that significantly influenced the course of Italian politics during 2005. The list of memorabilia should be sorted according to less spontaneous criteria than those that normally govern the daily news. Above all, we should at least attempt to reposition the processes in motion in a broader framework, which, 
for good or ill, usually has the effect of making what may have seemed "decisive" at the start somewhat less important.

Our first task, therefore, is to evaluate critically the commonly available information concerning the events surrounding the relationship between the state and the Church in Italy during the two six-month periods of 2005. Too often it has been supposed that the papal succession in April and the referendum on law no. 40 in June necessarily constitute the decisive events and turning points of that relationship. It is taken for granted that it is precisely in those experiences that the Church changed its way of acting on the public stage, that thanks to the new pope's anti-relativistic verve and the easy success given by the electoral mechanisms of the referendum, the Church decided (to use a soccer metaphor) to enter the political arena with a sliding tackle, without worrying too much about fouling the right leg of the partisan spectrum, and with even less regard for the left. Each of these popular theses has, obviously, some foundation. Nevertheless, a more profound examination is necessary, taking into account the lines of development that the Italian Church has followed throughout 2005. In this chapter, then, I will first consider the phase of the papal succession and then the Church's attitude toward the referendum in June. In addition, I will analyze the significance of the intense activity of the Conference of Italian Bishops (Conferenza Episcopale Italiana, CEI), the statements and the appointments resulting from the summit of the same conference in the first months of the new pontificate, and the question of the plurality of viewpoints within the Italian Church.

\section{The Death of John Paul II and the Papal Succession}

There is no doubt that the papal succession-marked by another smarting defeat of the contingent of Italian cardinals, unable to find among themselves a man worthy of ascending to Peter's throne-was, starting from the build-up to the conclave, an important event for Italian politics as well. In fact, during the weeks of the Pope's deteriorating health, it did not pass without notice that problematic characteristics of Catholicism - and of Italian Catholicism, in particular-were coming to light.

On the one hand, the way in which the Church and the press synchronized themselves in following the final phase of the Pope's long illness was indicative. The papal court's decision to secrete itself and to hide the seriousness of John Paul II's illness was not as such something that was imposed on the media or on the Church. Nonetheless, the question of who was making the decisions for the Pope in those final days and in those final hours was not raised, not even when the last two dozen 
appointments were announced, without fear of scandal, on 1-2 April, when the Pope was already in the throes of death. At the same time, however, the Pope's suffering, especially in his last heart-rending, mute appearances at the window of the Apostolic Palace, was not the least bit filtered, neither for the mass media nor on the pastoral level. From the open-camera car that brought the Pope back from the Gemelli Hospital to the Palace, to the search for the feeding tube in the photographs of Easter devotions, the television and photograph industries dwelt pitilessly on the most excruciating details, almost like a "reality show."

Conversely, the response from the diocese of Rome and the local churches followed the most routine lines. There were some more or less solemn liturgical intercessions, but a certain stiffness took hold that reached its apex during the last night of Pope Karol Wojtyla's life, when no one managed to celebrate the mass before a packed St. Peter's Square. In comparison, Cardinal Luigi Traglia had been able to say that mass for John XXIII in 1963. The loving and morbid attention surrounding the Pope's illness provided visual confirmation, once again, that the unity of the Church during Wojtyla's era did not come from a profound communion, sacramental in structure and shared among the parts of the Church. Rather, it confirmed that the unity came from the fact that all of these parts-without recognizing each other, or even in order to avoid recognizing each other-turned to the Pope as the holder of a new primacy of communication. Therefore, from the media's point of view, they accepted and suggested the journalistic simplification in which the death throes of a man, ill and beloved like John Paul II, were represented by focusing the camera on him, as if the last and only Catholic was dying.

On the other hand, the organization of the mourning for the death of John Paul II demonstrated an intensity of participation, both quantitatively and qualitatively, that was of great significance. The Poles came, as did pilgrims mobilized by movements that owed him so much, and the curious poured forth from every part of the world, all to pay homage to the mortal remains of the Pope of the Jubilee. In addition, a significant number of everyday Catholics rushed to pay their respects. These Catholics frequent the parish and attend Sunday mass, but they are not as numerous or as manipulable at election time as some politicians believe. In any event, they still represent today one of the collectivities most ingrained in the fabric of the country-one that is more likely to organize itself than to be organized.

In this mystical-media framework, a conclave took shape that had some original elements. The deafening media noise around the vacant Holy See was in fact an over-amplified rustling that replaced a collective discussion of the state of the Church, like those particularly 
vibrant and fruitful conversations that took place in other similar circumstances during the twentieth century. The "press silence" imposed on the cardinals, which had no grounds in the apostolic constitution Universi dominici gregis that John Paul II published in 1996 to regulate the election of his successor, was a fragile innovation. The press and the television stations did not attempt to penetrate this silence with any of the stratagems typical of these circumstances, which usually sharpen journalistic ingenuity because of the very lack of communication. Hypnotized by the enormous crowd that came to Rome, the media refused to reflect on the meaning of this affection for the dying Pope, on the hypocrisy and tame lies flying around the media circus, on the difficulties and the hesitations that punctuated this phase, nor on the fact that no one could account for a grief that overflowed far beyond the boundaries of Catholicism.

A mystical atmosphere even conditioned the interest in the proceedings of the imminent conclave. In April, the floods of discussions and conversations surrounding the preparation for the conclave were sprinkled with some allusions to the prospect of the return, after a quarter of a century, of an Italian papacy. The candidacy of Cardinal Dionigi Tettamanzi seemed to many observers a realistic hypothesis, and it would have meant (as a hypothesis, without considering the outcome) the recognition of the rediscovered pastoral credibility of the largest episcopate in the world. In opposition to Tettamanzi, there was talk of a possible candidacy from Cardinal Camillo Ruini, who, as the newspapers reported, would make a very clear political mark on the peninsula, or-symbolizing a more international political vocation-that of the secretary of state, Angelo Sodano (theoretically penalized by age, which, in the end, did not constitute a problem), whose political vision was broader and more universal. In reality, there does not even seem to have been a conflict between the Italians as there was in the second conclave of 1978, which benefited Wojtyla. And perhaps (admitting for the sake of argument that the fragments of an anonymous diary that Lucio Brunelli used on TG2 television and that then appeared in Limes are authentic) they did not even line up behind the candidacy of Martini, though this seemed or seems plausible to some.

Whatever the case, the Italians at the conclave did not have any weight, whether because of the illusory expectation of a chance that never arose, or in order to avoid too sharp a conflict. Not even the packages of votes that they are supposed to have moved did so autonomously. Rather, they followed the general movements of the college, which (according to the diary Brunelli made public) hesitated on the name of Joseph Ratzinger on the morning of 19 April-a hesitation that was potentially fatal for his chances-and then, after a few hours, 
broke through the threshold of a qualified majority, electing the Bavarian cardinal to succeed the Polish Pope.

Now with the conclave concluded so rapidly, has a new era begun? Time will tell. But in narrative terms, the portrait of Benedict XVI has been sketched: he is a man who has expressed everything he believes, in the categories of the end of the Wojtylian pontificate, in a large library of works and acts of doctrinal government. Crowd presence, communicative ability, the power to intervene in public debate, and verbal activism are measured in vain because not one of these parameters seems to be relevant to a Pope who is, above all, a theologian and a non-Italian. While the news media have a strongly retrospective viewpoint on his papacy, Pope Ratzinger is looking for his own way. He celebrates mass without emphasis, prays without the presence of television cameras, speaks little, does not travel, avoids contact with the masses, and, above all, holds his decisions in abeyance. By the end of 2005, he has made hardly any decisions, and those he has made are hardly indicative. For example, he shortened the synod, nominated an American bishop to the ex-Holy Office, wrote something for an encyclical originally announced for the fortieth anniversary of the close of the Vatican II Council-and then put it off until 2006. But he has not put his hand to anything else. While we wait for the "great papal surprise," which some of the defeated cardinals continue to talk about, we can only make the most of some remarks (the denunciation of the tyranny of relativism and of the hypocrisy of tolerance in secular states), scrutinize the audiences given (to Oriana Fallaci and Hans Küng), decipher the political relationships (like the one with the speaker of the Senate, Marcello Pera, which consecrated him as the interlocutor of that part of the lay ecclesial movement, Communion and Liberation [CL] that is active in the Casa delle Libertà), and analyze the silences (like the one over the fortieth anniversary of the Vatican II Council).

One of the most serious problems during the final phase of Wojtlya's pontificate was the internal antagonism within the papal court, and it has not been resolved. The secretary of state, who was most committed to stemming the autonomous activities of the papal apartment and John Paul II's most intimate circle, not only has been reconfirmed but has been reappointed without any qualifications and therefore, at least in theory, for a five-year term, or until his 80th year. The heads of the departments of the Curia have been reconfirmed, donec aliter provideatur (until other provisions are made), which leaves open the possibility of a turnover in the Roman Curia. If this turnover were carried out according to the canonical norms regarding age limits, it could redraw the map of power in the Church's government. 
If, therefore, anything relevant happened to the Italian political scene in April, we should not look for it in the succession to the pontificate, the consequences of which will become clear in time and stretch well beyond the narrow confines of the peninsula. Rather, we should see it in the fact that the representation of the Church has been crystallized in a simplified form that is laden with possible effects, and that the CEI, as a result of this further extension of the period of "foreign" papacy, will remain the organ designated to decode Italian politics for the Pope, and vice versa.

\section{The Referendum}

Two months after the papal succession, the Church once again became a major participant in political debate, with its commitment to the campaign on the referendum on law no. 40/2004 and with the success it achieved. ${ }^{1}$ Though the CEI claims to have been "forced" to take up the referendum challenge, it had also constructed it when it galvanized Catholic politicians to ensure that the passage of law no. 40 in the Senate would take place under the banner of nihil innovetur (nothing should be changed). And the referendum challenge was significant. It should be analyzed alongside the papal election proceedings, certainly not in a strict comparison, but for the very different ways in which it was analyzed both in the news media and within the Church itself. The success of the masses of non-voters in blocking the abrogation of the law on artificial insemination had the force of a fact that was eloquent testimony in and of itself. Cardinal Ruini, knowing that abstention had reached comparable levels in the failed referendum votes of the past decade, was the first to deny exclusive credit for that mass of votes. At first, he even found himself in the extremely difficult position of having to "defend" the abortion law, insofar as he gave assurances on live television that the Church was not going to use this easy victory to launch a far more alarming attack on law no. 190. Then, in the space of just a few months, he raised the question again in different terms.

In any event, more than a few people believed, whether with enthusiasm or regret, that in the referendum result they were seeing a kind of epic event. They saw it, in turn, as the comeback victory after the lost referenda on divorce and abortion; the beginning of a neo-centrist recovery; the refoundation of a Catholic activism unburdened by Christian Democratic mediation; the embryo of a clerical-conservatism that flavored the American "theo-cons" with a papal sauce; an assault on the principle of secularism; the end to the separation of church and 
state, prompted by Ruini's hatred of Romano Prodi; the predominance throughout the entire Church of a new obsession with politics; or the triumph of the newspaper Avvenire-a David against the news media Goliaths, Corriere della Sera and La Repubblica-and the dawning of a new counter-reformation that is setting out to reconquer control over the human body.

In this clash of interpretations, a more internal facet of the make-up of the Italian Catholic Church lies in the background. Though it may be true that there was no internal conflict among the bishops over how to deal with law no. 40 (even if it is well known, for example, that Monsignor Carlo Caffarra did not consider the law strong enough and that Cardinal Tarcisio Bertone in fact broke up the diocesan hospital team who were treating infertility within the limits of law no. 40), nor was there any conspicuous dissent from the instructions of the president of the CEI on the referendum campaign, it is also true that this took place in an atmosphere in which dialogue was limited, both between bishops and within the Church as a whole. Even the position of a dean of the most conservative Catholic philosophy, such as Giovanni Reale, editor of the Pope's writings, was made the object of extensive condemnation in the newspaper Avvenire when he reached conclusions different from those of the CEI president. Reale was not even afforded the opportunity of a plea bargain. The action of the electoral committee Science and Life was ancillary to the political line dictated by the bishops in January. This way of operating recalls the Civic Committees that Luigi Gedda constructed in order to condition the Christian Democrats. Instead of showing the significant shades of difference that existed among the promoters as among the defenders of law no. 40, these organs lumped them all together, so as to hold up to public scorn within the Church almost all Catholics who hinted at risks, negative consequences, or problems resulting from abstention (almost all, because there was evidently an indulgence for the president of the Republic, Carlo Azeglio Ciampi, and his wife).

In this way, abstention, a clearly legitimate position, which just as clearly does not involve taking a bold ethical-political stand, became a dividing line. It was used not so much to distinguish the good from the bad or to stimulate an analysis of how it is possible to make decisions on scientific questions or to reveal the differences between approaches or the ethical consequences of various religious traditions. Rather, it served to trigger an internal dialectic within the parties and the coalitions. Betraying a fairly naive vision of the Church, politicians were more worried about not losing the electoral booty that the CEI president would be able to procure for them by indicating to the bishops to indicate to the parish priests to indicate to the laity how they should vote. 


\section{The Unknown Side of the CEI}

The media's superficial treatment of the year's events should, then, be looked at with caution-not because it reflects the minor episodes, but because the bright light it radiates can cast a shadow on the slower and longer processes, which need a wider temporal context in order to be understood. In fact, although its agenda is still to be determined, the National Ecclesial Congress in Verona in the autumn of 2006 is already in view. Thus, it is ever more necessary to keep in mind the ordinary action of the Conference of Italian Bishops, which held its general assembly in Rome on 18-22 April, and reassembled in Assisi on 14-17 November. This action is carried out on various levels and is rarely considered, although it combines rhetorical exercises and indications of more profound tendencies.

On one level, there are the interventions oriented more toward the internal life of the Catholic Church that come from the presidency of the Conference or from its commissions. Such interventions often fall into the silence of the grave, but they are indicative of a level of interest and of complex expectations, and as such merit our attention. Let us turn now to look at the most important ones that took place in the course of 2005.

First of all, the year opened with a document on Jewish-Christian dialogue, dated 17 January. It was signed by the president of the Commission for Ecumenism and Inter-religious Dialogue, who was then Monsignor Vicenzo Paglia, bishop of Terni-Narni-Amelia and ecclesiastical assistant of the community of Sant'Egido, and by Rav Giuseppe Laras, then the chief rabbi of Milan. This strongly worded document, which reaffirmed the sense of mutual sensitivity and a common reading of the scriptures, was published precisely when the virulent discussion exploded between the accusers and defenders of Pius XII's action during the Shoa, prompting suspicions of broader aims related to the issues raised by Pope Pacelli's actions. ${ }^{2}$

On 25 January, the membership of the preparatory committee for the 4th National Congress, to be held in Verona in September 2006, was finalized. ${ }^{3}$ Cardinal Dionigi Tettamanzi was named as the chair of the committee; he was the leading speaker at the 44th Social Week of Italian Catholics in Bologna (7-10 October), where he courageously broke with the policy of indulgence toward Berlusconi's government that the CEI had pursued until that point. The organizing committee of this "estates general" of Italian Catholicism plays a decisive role. Tettamanzi has three vice-chairmen (Luciano Monari, Francesco Lambiasi, and Cataldo Naro) and the secretary general, Monsignor Giuseppe Betori. In the giunta (executive committee), names of note 
included Paola Bignardi, the president of Italian Catholic Action (ACI), and Luigi Alici, who would become her successor a short time later. In addition, other well-known figures include Adriano Roccucci, from the community of Sant'Egidio, sociologist Luca Diotallevi, and theologian Franco Giulio Brambilla. The president of the CEI, for his part, nominated, among others, the president of the Christian Associations of Italian Workers (ACLI), Luigi Bobba; the rector of the Catholic University of the Sacred Heart, Lorenzo Ornaghi; the director of Civiltà Cattolica, Father Giampaolo Salvini; the Bolognese economist Stefano Zamagni; and the editor of Avvenire, Dino Boffo.

On 31 January, the Permanent Council of the CEI approved the statute of the new Missio Foundation, which, following the model of the other European episcopal conferences, concentrates and directs resources intended for the support of missionary work. As a strategic fulcrum of the international policy of the Italian Church (if only considering the weight that the cardinals from missionary countries have in the conclave), the new foundation constitutes an institutional venue that reduces the weight of the presidency of the CEI and brings different figures together in dialogue in order to define the orientation and methods of its aid to the Third World.

On 19 March, the Commission for Social Problems and Work, Justice and Peace published a document titled "The Rural World and the Italian Church," 30 years after a similar text was published by the CEI at the end of the pontificate of Paul VI. It is an analysis that brings together, if a little extrinsically, rural values and ecological sensitivity ("each farmer, faithful to the land ... feels himself a guardian of creation, with a responsibility to defend and improve it"), and offers suggestions for parochial life in these areas that are no longer the place of origin or the destination of young clergy. The note makes an appeal to politicians, asking them to promote the survival of rural communities, "especially in hilly and mountainous areas."

On 29 April, a document titled "Marriages between Catholics and Muslims in Italy" was published after a lengthy series of discussions among Catholic regional organizations, groups of experts, and agencies. It is a document that is harsh in tone and (alone in Europe) aligned with the theses of the Pontifical Council for the Ministry to Migrants, which suggested, in 2004, a policy of discouraging mixed marriages: "Marriage between Catholics and non-Christian migrants should be advised against, though with varying firmness, according to the religion of each person, excepting special cases, in accordance with the norms of the codex iuris canonici (CIC) and of the codex canonum orientalis ecclesiae (CCOE).” The CEI considers the juridical and canonical problems stemming from disparitas cultus, or the spouses' 
membership in different religions, in great detail (at the end, there is a form to fill out). However, it does not consider the dimension of reciprocal love in the same detail, although its existence is not ruled out. In any case, given the civil implications of religious marriage and of its eventual annulment in a situation of disparitas cultus, the explicit suggestion is to consider the matter with extreme caution. This is not without significance for politics more generally. ${ }^{4}$

On 10 April, the referendum climate was already being felt in a message issued for the day of fund-raising for the Catholic University of the Sacred Heart. Three years after the CEI had intervened to cut short Sergio Zaninelli's rectorship (perhaps because he was guilty of not bowing sufficiently to the claim of CL to hegemonize the university) and had promoted the rise of the political scientist Lorenzo Ornaghi, the Conference announced its support for the university "particularly in the crucial area of genetic, cellular, and clinical research, knowing that the Catholic University of the Sacred Heart is deeply aware that science must never omit consideration of ethical and spiritual concerns. For this reason, the Italian Church invites the university of Italian Catholics to instill in its different components a responsibility for the fate of humankind, in a multi-disciplinary exchange that is capable of demonstrating how each truly significant scientific advancement attracts the contributions of many other fields of knowledge." 5 It is a message, then, dripping with themes from the referendum propaganda but also containing allusions to the initiative of Don Pietro Verzé, founder of the San Raffaele medical empire. Verzé had flanked his scientific laboratories with a private university and a philosophy course given first by Massimo Cacciari and then by Ernesto Galli della Loggia.

On 15 May, the Episcopal Commission for the Doctrine of the Faith published its note titled "The First Announcement of the Gospel," an instrument geared toward evangelization that reflects how both the significance of the Christian message and its most critical points are viewed from within the episcopate. Soon after, on 30 May, the outline drawn up for the Congress in Verona was approved. This kind of document offers more precise indications on the Congress's general theme ("Witnesses of the Risen Christ, Hope of the World") and follows the model of the first letter of Peter. The biblical reference introduces variations on the five themes of debate (personal relationships, work and holidays, the fragility of creation, tradition, citizenship ${ }^{6}$ ) for the assembly, now scheduled to take place on 16-20 October 2006.

During the course of the abovementioned CEI assembly in Assisi, the document on the preparation of presbyters and on seminaries was approved. It attempts to introduce an idea of community life into the 
seminary (the propaedeutic community, the rules of communal life), in reaction to the impression of a hegemony over vocations exercised by the movements, which could aggregate their own seminarians on a national scale and intimidate the dioceses. ${ }^{7}$

The acts that we have briefly reviewed are not without political import, if only because they demonstrate that the most pressing concern of the bishops-or at least of the majority of them-when they meet is not in the first instance the changing Italian political scene but rather the problems of Christian life as it is actually lived. These CEI proceedings often are not classifiable along simple partisan lines. They bear witness to a pastoral attention that exists in the organization of the Conference and whose major political significance is precisely that it is distinct from the political agenda. The latter, however, is never absent from the meetings of the Permanent Council nor from Ruini's inaugural addresses.

\section{Inaugural Addresses and Appointments}

One original characteristic of the CEI, compared to other national episcopal conferences, concerns the method of work of the presidency (consiglio di presidenza): the vice-presidents of the Conference (the highest elective office, as the CEI is the only conference in the world presided over by a bishop selected by the Pope), are members along with the chairs of the commissions that produced the abovementioned documents. The presidency begins its work with an address by Cardinal Ruini and then most often is reduced to-at least as far as its work is made known to the public - a defense of the controversial political passages that, by now, the news media expect in Ruini's inaugural addresses and that make the rest of his speech seem like padding.

This explains why an episcopal conference that is much more politicized than the others ends up appearing at a loss when very important themes appear on the political horizon. Take, for example, the constitutional reform introducing devolution, which potentially exposes Italy to the risk of a marked division (for instance, should the referendum on the reform highlight the difference between some northern regions and the rest of the country), but no less exposes the Holy See to instability, which was precisely what the presence of Article 7 in the Constitution was supposed to avoid.

The inaugural addresses, in fact, can develop only immediate political themes, as a brief investigation of their language and their structure demonstrates. A careful analysis of Ruini's inaugural addresses-one that would include their lexicon, implicit sources, rhetorical expression, 
accessibility to the media, and selection or omission of themes-is still wanting. But a cursory reading reveals that no current political topic, no matter how small, is ever overlooked. From an appreciation of the solution of the crisis of Fiat to a constitutional challenge to the possible law on fiscal and contractual privileges for common-law couples, from the iron and steel industry to public works, from taxation to wiretapping-Cardinal Ruini's ability to evoke resonance from the political chords of journalism is such that the proceedings of the ecclesiastical government, the pastoral work of the bishops, the internal dialectic, and finally the background of appointments and internal elections never receive media attention as part of the representation, or self-representation, of the Church.

In 2005, the elections and new appointments within the CEI, for example, were particularly significant and gain increasing importance because, with the papal succession and the passage of time, the leadership of the CEI is destined to be reconstituted, either because any changes will alter the make-up of the organization, or because any confirmations will make it more stable than it appears today. Besides the appointments for the Verona assembly (which we can read as an indication of the favored and less-favored areas of the Church, hardly balanced by the appointments at the level of the regional conferences) the CEI in fact filled, for the next five years, the chairmanships of its own working commissions and of the Council for Economic Affairs. ${ }^{8}$ In addition, it elected two new vice-presidents in the persons of Monsignor Luciano Monari, Archbishop of Piacenza, and Monsignor Giuseppe Chiaretti, Archbishop of Perugia.

While in the past the vice-presidency was given to cardinal archbishops, now two personalities who possess a marked spiritual quality and who have been bishops for a decade fill the position. Monari comes from the clergy of Reggio Emilia, where Cardinal Ruini also served. His background as a biblical scholar and spiritual guide has always kept him far away from the political and anthropological arenas that are more familiar to his older confrère. Chiaretti comes from the Rieti clergy and was formerly bishop of San Benedetto del Tronto before his appointment to Perugia. He is one of the Italian bishops with the best preparation in ecumenical subjects and belongs to the plenary of the Pontifical Council for Christian Unity. Neither of these two was chosen as an antagonist for Cardinal Ruini, as far as the centrality of politics in the mission of the CEI is concerned. Objectively, however, a spiritual and pastoral profile such as theirs has become increasingly necessary for a presidency that for years had a not always welcomed counterweight in Cardinal Martini, who in any case effectively "covered" interests and areas of activity that were otherwise 
ignored. Ruini's presidency also benefited from the intensity of faith stimulated by the charismatic figure of Wojtyla that kept in balance the several political and cultural "levels" of the Conference's activity, which are as many in number as they are monotonic in outcome. ${ }^{9}$ Neither of these two new vice-presidents voiced any doubts during the campaign for tactical abstention from voting in the referendum. Yet at the same time, neither is the kind of bishop who is willing to accept developments in the political arena in order to be able to satisfy goals in the pastoral sphere.

The manner in which the new make-up of the presidency will face the delicate political season ahead is still to unfold. The return to a proportional electoral system for the 2006 general election could suggest the introduction of an ethical dividing line (rights of the embryo, same-sex unions, and, above all, euthanasia) that would keep the hierarchy even more in the center of the debate, if it chooses to pick out candidates who are ready to become spokesmen for those causes, at least in principle or in a purely instrumental way. Conversely, it could allow for the return to a leadership that opts for rewarding those Catholics who bring to politics a desire to heal divisions, leaving them to find the necessary ways and means.

\section{Freedom of Speech}

Alongside the climate of the new pontificate, the continuing emphasis placed on the referendum victory, and the new power balance within the CEI, the quality of the dialogue within the Church itself also plays a crucial role in redefining the relationship between church and state. The central political issues belong, by definition, to that area of action on which Catholic doctrine can shed some light, but which as such is the subject of general debate leading to conclusions that are fallible, questionable, and provisional with respect to the ultimate goals of justice and peace. The Church in its wisdom meant to underline this aspect by forbidding the clergy to take on active political roles. And the history of republican Italy has shown that the Catholic Church most successfully contributed to the democratic life of the country when it was able to educate men with great intellectual stature and a deep sense of public morality who bore testimony to the fruitful results that could be achieved by a practice of dialogue and freedom of thought born from Church experience that was pursued within the Church as well, and even against the line that it itself indicated.

These kinds of men appeared in the most varied incarnations: Alcide De Gasperi was quite different from Giuseppe Dossetti, as was Aldo 
Moro from Beniamino Andreatta. The problem that we find now facing the Church, and thus also indirectly facing politics, is that today that type of training is very limited in the actual practice of the Catholic experience. Similarly limited is the horizon of thought concerning the most wide-ranging issues of social life (Alici highlighted some in the report just cited). These issues simply cannot be reduced to an ethicalmoral questionnaire with set answers, which gives zealots and opportunists higher scores than the liberal-minded and the scrupulous.

Some lay organizations-for example, CL, whose leading group formed between the late 1960s and the end of Montini's pontificate and has been left since 22 February 2005 without the charismatic leadership of its founder, Don Luigi Giussani-are also quite visible in the political sphere. Nevertheless, these movements make up but a small fraction of a large Catholic community. Franco G. Brambilla has correctly noted that despite its shrinking numbers, the Church still totals today 7 or 8 million people who regularly attend Sunday mass in Italy's thousands of parishes. It also includes priests who do not aspire to become bishops and militants who do not pursue political positions or contracts in the name of the "visibility of the faith." Some opportunities for discussion have also arisen, stemming from unpleasant events such as the European Parliament's veto of the appointment of Rocco Buttiglione to the Commission of the European Union, or the heckling of Cardinal Ruini by a small group of troublemakers in Siena. In the first case-a possibly malicious parliamentary trap, but one that was certainly elementary in comparison with what happens at the confirmation hearings of the US Congress-Buttiglione's defenders cried persecution. They did not pay much attention, however, to the issue of the relationship between individual rights and the moral opinions of decision-makers, which will certainly come up again. In the second case, Church spokesmen castigated the lack of respect shown to the cardinal. However, they did not question the correctness of the CEI president's accepting an honor offered by an old political hand and by an institution unable to guarantee the winner of its "Liberal of the Year" award an undisturbed ceremony.

Above all, it would be appropriate to examine the faith's ability to humanize this life on earth and those who live it. But in the Catholicism of today, as Enzo Bianchi wrote in a serious and bitter tone on 30 November in La Stampa, the inclination toward dialogue is increasingly less widespread. Some bishops may even be pleased about this, if they confuse silence with obedience, passivity with humility, and indifference with docility. And even some politicians may delude themselves that this will make electoral negotiations with the Church easier, as they may think that once the president of the CEI, or a 
movement that illegitimately claims its support, has been persuaded, everything will be resolved. In reality, precisely the opposite is true. In this bitter silence, barely broken by a few discontented murmurs that are immediately extinguished by press statements, neither Christian nor civic virtue can grow.

\section{Concluding Considerations}

While a broader perspective on the new pontificate and its effects on political debate will naturally come only with the passing of time, the elements quickly touched upon in this chapter point out in any case that the relationship between Catholicism and Italian politics must be examined taking into account the linguistic simplification (common to, but just as perilous in, Italian public discourse) that speaks of "the Church" in a rather loose way. In fact, when we say "the Church," we are talking about something of such large and complex dimensions that it is impossible to confine it within the categories of everyday politics. A community that surpasses a billion faithful is represented in Italy not only by great events and by the media's presentation of it (necessary or mercenary, as the case may be), but by many Catholics, very different from each other on the spiritual plane as well as on the political and electoral level. There is no denying that between a neo-catechumenal and a Lefebvrian Lepantis $\mathrm{t}^{10}$ stands an impassable political division, whatever the parish priest, the bishop, or the CEI says.

In sum, we can say that especially after the fateful year 1989, the orientations of Catholics are as diverse as those of the country and do not automatically follow a chain of command leading from the CEI president down to the parishioner of the suburban church. And if it occasionally seems like this happens, it is not due to the strength of the hierarchy but for the opposite reason: the territorial rootedness of the "everyday Catholics" is, in fact, so deep that it transmits a sort of political shudder from the ground up, which the Church absorbs so quickly that whoever is not watching closely would think that the Church had moved votes, when in actual fact they shifted it or even split it apart. Because the Church did not create doroteismo (Dorotheism), ${ }^{11}$ Christians for socialism, Christians for the "no," the Catholicism of the Lega à la Pivetti of a few years ago, and not even, in this past year, the boycott of the artificial insemination vote-as much as it may warm the hearts of those who believe they have set up a milestone in the history of the Church itself to think so. All of these processes have been the fruit of a complex, two-way dialectic that either has been subject to or has exploited the choices of others and does not 
constitute proof of temporal power. In a time when politicians seem uncertain of their own reasons and have lost their innocence, there is a widespread idea that in order not to run any risks, it is wise to get or request ecclesiastical support-or conversely, to position oneself in opposition with some attention-seeking statements. But this has little to do with the Church-in the proper and broad sense.

Is it then a question that concerns Ruini (referred to now by his last name like a politician, both by his devoted followers and by his Sienese hecklers)? There are many distinctions to be made here as well. The CEI is very new; it originated during the Vatican Council II, endowing Italy with an institution that other countries had known for decades. Out of respect for the Pope, the primate of Italy, it was decided that the Conference of Italian Bishops, however, would not elect its own president but rather would have him named by the Pope. And Paul VI, in order to make this senate of bishops work, made it his business to appoint presidents who were ready to implement his political intentions (Urbani, Poma, Ballestrero), and secretaries general who would broaden its political horizon (the most important of whom was Bartoletti, who was given the task of organizing the referendum on divorce). With Wojtyla, things changed a little. After the parenthesis of Poletti (the first cardinal vicar also to become the president of the CEI), Monsignor Ruini became secretary general of the CEI in 1986, and then vicar of Rome and cardinal president in 1991. The Polish Pope had in Ruini not only a collaborator, but someone capable of explaining Italian politics to him, and of acting in that forum in the name of the Pope more than in the name of the bishops.

Nevertheless, the power of this "dictating the line," as Giuseppe De Rita correctly observes in La Repubblica, does not come from the cardinal, but from those who receive these ideas as amulets around which they dance the dance of obsequiousness (or toward which, as happened more recently, they address catcalls and whistles), even at the risk of praising principles they have not lived by or of contesting someone who is about to disappear from the scene. From this perspective, therefore, there is nothing less fruitful than accusing the Concordat, which devolution, as mentioned above, is threatening with dark clouds. Instead, what should be avoided-at least, for anyone who sincerely takes Christianity and the life of faith to heart-is the temptation to participate in the game of electoral flirtation/negotiation/ blackmail with the Italian Church, for this could only push the Church to act as a lobbyist. And even if it were a lobby for ethical causes, it is not good in a democracy for the Church to be reduced to a lobby. The Church, in fact, has the power that comes from maintaining the balance between principles and life, laws and acts of faith, tradition 
and fresh ideas. Certainly, there are circumstances in which it cannot recognize constraints and, when the world remains silent, must forcefully bear its own witness. But there are other circumstances in which all the points of view are already in play. In these cases, the Church should bear witness to the simple beauty of Christian life, lived as the fullness of humanity, and in so doing cause peace to grow in the City.

\section{- Translated by Sheila Das}

\section{Notes}

1. On the contents of law no. 40/2004, which limited artificial insemination, and on the referendum to abrogate parts of it, see Chiara Martini's chapter in this volume.

2. If the episcopal document did not get all the attention it deserved, the querelle on Pius XII (centering on the orders the Holy Office gave on the future of the French Jewish children who had survived the Shoa in Catholic institutions, which were cited in a review) was the occasion that sparked a violent and profound antagonism between the CEI's newspaper and the paper that had published the first report of the document in question, Corriere della Sera. The exchange of verbal blows was so harsh that Avvenire (never followed by the Osservatore Romano) went so far as to advise Catholics not to read the other newspaper. The Corriere in the meantime had announced to its readers its support for the "yes" side in the referenda on artificial insemination, which had now been called, and promised to give readers both sides of the issue. This historiographical episode had still other implications of political interest, specifically when, in the middle of January, the original document of the 1946 decision of the Holy Office was made public by Andrea Tornielli, a former journalist from Il Sabato, who had been working for many years at Il Giornale as a Vaticanist. Perhaps with a bit of naiveté (Tornielli and a collaborator of his did not understand that the interpolated clause "it is another thing if the parents were to come" referred only to unbaptized babies), someone decided to make an exception to the rules of access to the papers of the Secretariat of State.

3. Cardinal Ruini, in fact, was to complete his term as president of the CEI in February 2006, and at that moment (that is, before the election of a 78-year-old Pope) the fact that this deadline coincided with the age limit for active service in the episcopate, set by canon 411, could have led to the assumption that the Conference of Verona would be presided over by a new president of the CEI. (On 14 February 2006, Benedict XVI confirmed Cardinal Ruini as president of the CEI donec aliter provideatur [translator's note].)

4. It is noteworthy, I believe, that the question of the entry of Turkey into the European Union (the Turkey of the throne of St. Andrew, the Turkey of the secularism of Atatürk, the Turkey of prudent re-Islamization) is not a subject of debate: on 25 
January, the Permanent Council declared that it was in favor of enlargement, stating that "regarding the path of the European Union, the bishops underlined how the recent signing of the constitutional treaty commits the present 25 countries to its consequential ratification and to its concrete implementation specifically with respect to shared democratic principles, the full respect for religious freedom among them, toward which we hope may also converge those countries, like Turkey, which have received approval for the start of negotiations on entry." The line expressed by the CEI, therefore, is sharply different from the one Ratzinger supported as a cardinal. And it is unclear, even now, whether or not he has kept to the same line after succeeding to the Church's highest office.

5. The message is available on the CEI's Web site at www.chiesacattolica.it/pls/ cci_new/bd_edit_doc.edit_documento?p_id = 10457 .

6. On this theme, the most political, the outline goes on at length on the problem of citizenship, "in which the dimension of people's civil and social belonging is expressed." The questions for debate follow: What does Christian hope bring to the duty of citizenship? How can civic duty, while reflecting its social and political specificity, be a form of Christian testimony? How can we prevent interest in the big questions that confront citizens in our times from being reduced to a question of ideological battle lines, and instead stimulate forms of meaningful involvement? How can the social doctrine of the Church become a fertile point of reference? Both texts are available on the CEI's Web site (http://www.chiesacattolica.it).

7. This session also published a message to the nation on the fortieth anniversary of Vatican Council II and Monsignor Betori's reflection on the trajectory from the National Congress of the Church in Palermo in 1995 to the upcoming one in Verona.

8. At the end of spring, the chairmen of the episcopal commissions were elected: Bruno Forte (Chieti-Vasto) for the doctrine of the faith, the announcement, and the catechism; Felice Di Molfetta (Cerignola) for liturgy; Francesco Montenegro (auxiliary of Messina) for charitable services and health; Benvenuto Italo Castellani (Lucca) for the clergy and the consecrated life; Paolo Rabitti (Ferrara) for the laity; Giuseppe Anfossi (Aosta) for the family and life; Luigi Bressan (Trento) for evangelization of the peoples and cooperation between churches; Vincenzo Paglia (Terni) for ecumenism and dialogue; Diego Coletti (Livorno) for Catholic education, schools, and universities; Arrigo Miglio (Ivrea) for social problems and work, justice, and peace; Cataldo Naro (Monreale) for culture and social communication; and Lino Bortolo Belotti (auxiliary of Bergamo) for migration. The bishops of Susa, Savona, and San Benedetto del Tronto and the auxiliary bishop of Milan were also elected members of the Council for Economic Affairs.

9. In December, the CEI held a summing-up conference of the Committee for the Cultural Project, during which the new president of the ACI, Luigi Alici, gave an important report on "the crisis of anthropology and the infinity of the person," finishing with a plea for a "free coming together" of Catholics in politics around major ethical and moral issues.

10. The neo-catechumenal movement began in the shantytowns of Madrid in 1964, inspired by John XXIII's words "Christ is present among the poor"; Archbishop Lefebvre rejected the innovations of the Vatican II Council; the Lepanto League is an organization of conservative Catholics (translator's note).

11. The dorotei were for many years the dominant centrist faction in the Christian Democratic Party (translator's note). 